\title{
SUSTAINABILITY REPORTING IN THE NORDIC REAL ESTATE COMPANIES: EMPIRICAL EVIDENCE FROM FINLAND
}

\author{
Anahita RASHIDFAROKHI ${ }^{1, *}$, Saija TOIVONEN ${ }^{1}$, Kauko VIITANEN ${ }^{1}$ \\ ${ }^{1}$ Department of Built Environment, School of Engineering, Aalto University, PO Box 14100, FI-00076 Aalto, Finland
}

Received 11 July 2016; accepted 13 January 2017

\begin{abstract}
The purpose of our study was to investigate the content of sustainability reporting issued by real estate sector. Content analysis was employed to identify the strengths and weaknesses of sustainability information provided by sample companies. The content analysis structure considered both quantity and quality of information simultaneously. Our results show an inconsistency in the form, extent and quality of sustainability reports. In addition, our findings recognise a lack of clear approach to embrace materiality, external assurance, and further engagement of stakeholders in the sample reports. It seems that most of the sample companies were engaged in issuing sustainability reports to fulfil the legislative requirement and avoiding financial or legal risks. Our study provides information on the current status of sustainability reporting to real estate professionals. In addition it contributes in decreasing the financial and legal risks, and increasing the corporate reputational capital, by revealing the common weaknesses prevalent in the sustainability reports.
\end{abstract}

Keywords: sustainability reporting, listed real estate companies, quantity and quality of sustainability information, content analysis, Global Reporting Initiative.

Supplementary material associated with this article can be found, in the online version, at https://doi.org/10.3846/ijspm.2018.321.

\section{Introduction}

The real estate sector introduces significant impacts on the natural environment, society and economy (Wilkinson \& Sayce, 2015). In response to these impacts, sustainability has emerged as a guiding paradigm for real estate developments to 'meet the needs of the present without compromising the ability of the future generations to meet their own needs' (Brundtland Commission, 1987). Finding holistic solutions to integrate sustainability with the real estate sector has led to the emergence of a large body of literature (Pearce \& Vanegas, 2002). Despite the attempts, still no comprehensive and unified definition of sustainability exists that satisfies all the stakeholders (Byrch, Kearins, Milne, \& Morgan, 2007). This can be due to the contested nature of sustainability and sustainable development concepts (Paton, 2010), in which endless arguments on their applicability are proposed by stakeholders, and that cannot be settled by referring to empirical findings or logic (Wilkinson \& Sayce, 2015).

Similarly, Corporate Social Responsibility (CSR) is regarded as a contested concept. Okoye (2009) has argued that CSR needs to be flexible in order to allow the emergence of different conceptions. The different conceptions reflect the diversity of actors and issues (Okoye, 2009). Tsoutsoura (2004) has described CSR as policies, practices and programs that integrate into business processes in a company and usually embrace a number of issues, traditionally framed as business ethics, community investment, environmental concerns, corporate governance, human rights, and the marketplace and workplace.

The European Union (EU) has strongly promoted the concept of CSR (Yildiz \& Ozerim, 2014). Reporting on CSR, also known as sustainability reporting, is assumed to significantly enhance the integration of CSR into core business processes and stakeholder management (Wensen, Broer, Klein, \& Knopf, 2011). In sustainability reports, companies publicly disclose their sustainability strategies and corporate performance, be they positive or negative (P. Jones, Comfort, \& Hillier, 2015; O’Dwyer, Unerman, \& Hession, 2005). Sustainability reports offer new opportunities for corporate sustainability in real estate sector (Glass, 2012). They enable companies to communicate their sustainability performance, which results in higher transparency (Glass, 2012), and lower level of material and economic risks (Elkington, 2004). In addition, sustainability reports contribute in achieving reputational capital (D. L. Brown, Guidry,

${ }^{*}$ Corresponding author. E-mail: anahita.rashidfarokhi@aalto.fi 
\& Pattern, 2009; Crowther, 2003; Idowu \& Towler, 2004), and competitive advantage (P. Jones et al., 2015; Ioannou \& Serafeim, 2011) as a reward for companies' environmentally and socially responsible behaviour.

Today, sustainability reporting has become a standard practice and growth has continued (KPMG, 2015). The current sustainability reporting practices, which include more social and environmental performance measurements, follow an earlier corporate voluntary reporting in the 1990s that tended to disclose narrative information on the selected environmental, community and employee issues as part of corporate annual reports (Milne \& Gray, 2013). However, issuing sustainability reports is still a volunteer-based practice in most of the European countries (Carrots \& Sticks, 2016; Bizzari, 2013).

Because of the voluntary nature of sustainability reporting, companies and especially real estate companies are faced with a lack of common global approach to standardise their sustainability reports. To fill this gap, some organisations, such as Global Reporting Initiative (GRI), International Integrated Reporting Council (IIRC), Global Real Estate Sustainability Benchmark (GRESB), and European Public Real Estate Association (EPRA) have created voluntary standard frameworks to achieve reporting unification, transparency, and comparability. However, the enforcement of Directive 2014/95/ EU, Disclosure of non-financial and diversity information, in the EU member states in 2017, will mandate the issuance of sustainability reports by large public-interest corporations. Large public-interest corporations are defined as the listed companies, banks, insurance undertakings, and other companies that are so designated by the EU members, with more than 500 employees (European Commission, 2016).

The emergence of the tightened sustainability policies in the Europe, can explain the increasing number of the real estate companies that engage in sustainability reporting practices. This viewpoint is supported by Tavares and Rodrigues (2016) and Cho and Patten (2007), who have believed that sectors which are subjected to tighter sustainability policies, are more likely to issue reports to address their environmental and social impacts.

Despite the rise in sustainability reports published by the real estate companies, to our knowledge, only few real estate sector-related research has been conducted (see Muhammad, Zulkipli, \& Haseeb, 2016; P. Jones, Hillier, \& Comfort, 2016; P. Jones, Comfort, \& Hillier, 2015; Stibbe \& Voigtländer, 2014; Andelin, Sarasoja, Ventovuori, \& Junnila, 2015; Andelin, Kyrö, \& Sarasoja, 2013; Glass, 2012). The majority of the mentioned studies as well as Jose and Saraf (2016) have found that the real estate sector faces challenges in pursuing sustainability reporting practices on the global scale. The limited number of relevant research, as well as challenges of the real estate sector in the context of sustainability reporting, is giving a cause to believe that further research in this field is necessary and valuable. Therefore, to contribute to the development of sustainability reporting knowledge in the real estate sector, our study aims to in- vestigate the practice of sustainability reporting, in order to identify the strengths and challenges around sustainability reporting practices in the real estate sector.

To address this aim, content analysis is employed to analyse the sustainability information issued by listed real estate companies in the Nordic context. The criteria for sample selection is based on the commercial real estate companies, which are listed and publish sustainability reports in Finland. Our study focuses on communication channels used by Nordic real estate companies for the year 2013-14. The proposed structure of content analysis by our study is one of the few to analyse both the quantity and quality of information available in the collected documents simultaneously. Such structure helps our study to provide a more concrete picture of the current status of sustainability reporting practices in the Nordic context to real estate professionals and academics.

The findings of our study have also practical implications for the industry, as they enable real estate companies to identify the common weaknesses prevalent in sustainability reports that need further attention. By acknowledging the shortcomings and taking further action, the companies can avoid the possible legal and financial risks generated by introduction of relevant legislations, such as EU Directive 2014/85/EU in 2017; and increase their reputational capital. This in the longer term will contribute in further integration of sustainable development in the real estate sector.

The rest of the paper is structured as follows. Section 1 presents the business motivations for issuing sustainability reports. Section 2 reviews the extant literature on sustainability reporting in the context of real estate. Section 3 depicts an account of the research methodology and sample. A review of key issues in the sustainability reporting analysis is presented and discussed in section 4. The last section ends the paper by providing the main conclusions, explaining the implication of the findings, limitation of the research, and recommending topics for further research.

\section{The business motivations for sustainability reporting}

The motivations and outcomes from sustainability reporting has evolved through time due to its growing strategic importance. Earlier, this motivation was mainly to increase the legitimacy and address social pressures (Deegan, 2002). Nowadays, motivations include other benefits, such as business (competitive advantage), social (stakeholder engagement), political (tighter policies), and accountability (Higgins \& Coffey, 2016; Hockerts, 2015; Higgins, Milne, \& van Gramberg, 2015). Our study focuses on the business motives for sustainability reporting due to the nature of the real estate sector. One of the business motives that has received attention by scholars and corporate managers is an increased reputational capital of companies (see D. L. Brown et al., 2009) achieved by publishing robust and truthful sustainability information (KPMG, 2015). 
Several researchers, including Kaspereit and Lopatta (2016), Reverte (2016), Chen, Ong, and Hsu (2016), Carnevale and Mazzuca (2014) and Lourenco, Branco, Curo, and Eugenio (2012) examined the correlation between high reputation for companies being sustainable and higher market valuation of earnings and book value. All the above-mentioned researchers agree that higher reputation for corporate sustainability leads to lower economic uncertainty, reduced information asymmetries, higher market valuation of corporate shares, more predictable earnings, and lower risk for investors.

Kajander, Sivunen, Vimpari, and Junnila (2012) assessed the impact of public announcement of sustainability innovations on the market value of the real estate companies. They have found a positive correlation between those two factors. Group of 100 (2004) has proposed that "effective communication with stakeholders can play an important role in managing stakeholder perceptions, and, in doing so, protect and enhance corporate reputation". Epstein and Freedman (1994) have defined a stakeholder of an organisation as a person that can be influenced by, or can himself influence the functions of that organisation. According to stakeholder theory cited in Gray, Owen, and Adams (2015), the more important the stakeholder in the company, the more effort needed to manage their relationship to further the interests of the company. Based on this theory, communicating sustainability information can be considered as an effective communication strategy employed by companies to manage their stakeholders to gain corporate reputation.

However, due to the volunteer-basis of sustainability reporting in the most of the European countries, sustainability reports have been criticised as being shallow and inconsistent in quality (see Muhammad et al., 2016; Glass, 2012; Andelin et al., 2013); narrative (see Higgins \& Coffey, 2016; Milne \& Gray, 2013); used as a legitimacy tool (see Unerman \& Zappettini, 2014; Zappettini \& Unerman, 2016; Stacchezzini, Melloni, \& Lai, 2016); and disingenuous (see Aras \& Crowther, 2009). If so, issuing sustainability reports could even influence the corporate reputational capital negatively.

Brown, D. L. et al. (2009) have proposed that the two following factors influence the corporate reputation through issuing sustainability reports: 1 ) industry sector to which a company belongs, and 2) quality of information. In their study, they have claimed that there is a direct link between quality of sustainability information and corporate reputation. The findings of Brown, D. L. et al. are in line with Burson-Marsteller's (2003) study of nongovernmental organisational perception of corporate sustainability information. Burson-Marsteller has found that employing comprehensive performance metrics and standard frameworks in issuing sustainability reports increases the reliability of information in the eyes of stakeholders.

In brief, from the arguments discussed above, it can be concluded that high-quality sustainability reports contribute in increasing the corporate value.

\section{Sustainability reporting in the real estate sector}

A combined search for the keywords "real estate", "sustainability reporting" and/or "CSR reporting", resulted in some studies that support the topic of our research. In addition, it gave an insight to the methods applied to conduct similar studies. Below, a brief description of these studies is provided.

Muhammad et al. (2016) conducted a study on corporate sustainability practices in 113 Malaysian listed companies in the property and REIT sectors. Their findings show that only 10 out of 113 companies engaged in sustainability reporting practices. Among those companies with sustainability reports, no uniformity existed in the reporting approaches. Social sustainability was the focal point of the sample reports.

Similarly, the findings of Glass (2012) on the state of sustainability reporting in the construction sector, show that this sector lags behind other sectors in issuing sustainability reports. Glass has found that construction companies used different sustainability concepts and their reports lacked consistency, and common standards to establish materiality. GRI (2013) defines materiality as follows: "The report should cover aspects that: reflect the organization's significant economic, environmental and social impacts; or substantively influence the assessments and decisions of stakeholders". Data durability, stakeholder engagement, and reputation management were other problems Glass has identified in the reports.

Andelin et al. (2015) investigated the largest Nordic real estate companies, to identify the investors' and tenants' sustainability drivers. Their findings suggest that although sustainability is seen as an added-value factor, the importance to communicate sustainability information via reporting is not yet recognised. Only $41 \%$ of the studied investment companies (total number of 42 companies) published sustainability reports annually. Among those, GRI framework was the most widely used framework and energy- and water consumption were the most common themes reported.

The findings of Andelin et al. (2015) are in line with those of Andelin et al. (2013) on sustainability reporting practices in 11 Nordic real estate companies based on GRI framework. Their results indicate that real estate companies lag behind other sectors in engaging in sustainability reporting practices. Their findings also show an inconsistency in the form, extent, and external assurance of the reported sustainability information. These trends were also observed before by Myers (2005) and P. Jones, Comfort, and Hillier (2006) among the listed construction companies in the United Kingdom (UK).

Brown, J. et al. (2009) assessed sustainability information provided by $12 \mathrm{UK}$ real estate companies. The research findings show difference in quality of the reports. Despite a consistent series of key performance indicators, no clear and consistent approach was identified to cover sustainability information. Carbon emissions and supply chain received the most coverage. T. Jones, Shan, and Goodrum 
(2010) in their study on the reports of 268 construction companies in the US have found similar deficiencies. Limited number of reports issued by construction companies, and inconsistent approach to the concept of sustainability were some of the problems they have identified.

The findings of Willetts, Burdon, Glass, and Frost (2011) on 20 global engineering consultancies, demonstrate inconsistency in forms and names of the report, the framework compilation, and applying external assurance. Environmental responsibility, health and safety, and community were the most frequently mentioned themes. Only two of the studied companies discussed about their stakeholders and only one company outlined their stakeholders' engagement process.

Caijas, Geiger, and Bienert (2012) investigated the effect of the sustainability agenda on the corporate level by studying the annual reports of 80 European listed real estate companies. Their findings show an increased level of sustainability information provision, especially in the fields of climate change, energy, social activities, and environmental aspects, and smaller increased coverage of human rights issues. In a study on corporate sustainability in the German real estate sector, Stibbe and Voigtländer (2014) investigated 135 German real estate companies for the implementation of CSR. Their findings show that although the German real estate sector, represented $15 \%$ of all real estate companies reporting based on the GRI in 2012 , they covered very few number of GRI indicators and were unable to address issues regarding the quality of their sustainability performance.

Jones, P. et al. (2015) in their study of the UK top 20 housebuilders, assessed the materiality and external assurance in their sustainability reports. They have discovered that only a few of the sample companies embraced materiality or applied external assurance on their sustainability information. In a similar study, on the 20 European leading commercial property companies, Jones, P. et al. (2016) have found that although all the studied companies had engaged in reporting practices, only about half of the companies incorporated materiality or employed external assurance in sustainability reporting processes. The findings from Jones, P. et al. (2015) and Jones, P. et al. (2016) undermine the credibility and reliability of the information provided by their studied companies.

Overall, from the extant literature review, the following conclusions can be derived. First, the real estate sector lags behind other sectors (Muhammad et al., 2016; Glass, 2012; Andelin et al., 2013, 2015; Myers, 2005). Second, there is a lack of consistent approach to sustainability reporting in the real estate sector (Muhammad et al., 2016; Glass, 2012; Andelin et al., 2013; J. Brown et al., 2009; T. Jones et al., 2010; P. Jones et al., 2006). Third, environmental sustainability is the most common type of information reported by real estate companies in the Europe (Andelin et al., 2015; J. Brown et al., 2009; Willetts et al., 2011; Caijas et al., 2012). Fourth, there is no clear approach to embrace materiality, external assurance of sustainability information, and stakeholder engagement (Glass, 2012; Willetts et al., 2011; P. Jones et al., 2015, 2016).

To our knowledge, so far, no previous research has analysed both the quantity and quality of the sustainability information issued by real estate companies in the Nordic context. Therefore, the results of our study serve as a platform to reflect the comprehensive picture of the current status of sustainability reporting practices in the real estate sector in the Nordic context.

\section{Methodology and sample}

Our study employed content analysis method in order to identify the strengths and challenges around sustainability reporting practices in the real estate sector, using empirical findings from Finland. First, this section provides an overview on the nature and characteristics of the real estate sector in Finland. Second, the sample selection procedure is explained. Third, the content analysis process and the coding system are detailed. Fourth, the applied techniques for validity and reliability of the research approach and results are presented.

\subsection{The estate sector in Finland}

The real estate sector in Finland accounts for the 25\% of the national GDP, $70 \%$ of the total national wealth, $65 \%$ of the investment, $20 \%$ of the Finnish workforce, and $20 \%$ of the taxation income (RAKLI, 2014). In 2015, transaction volume in the Finnish market exceeded $€ 5.5$ billion, and retail properties were the most traded type of properties (KTI, 2016). The Finnish commercial property development market is dominated by three (all listed) investment and seven (five listed) construction companies who have their core areas, both in Finland as well as in other countries, mainly in the Nordics (KTI, 2016).

The Finnish real estate sector is responsible for over $40 \%$ of energy consumption and $35 \%$ of $\mathrm{CO}_{2}$ emissions on the national level (RAKLI, 2014). The greatest sustainability challenges for the Finnish real estate sector are the integration of climate change mitigation and adaptation strategies, ageing population, internalisation and urbanisation, energy retrofitting of existing buildings, and the vacancy rate of the office premises due to the changes of work and space requirements (ROTI, 2011).

\subsection{Sample selection}

The sample used in our study includes Finnish listed real estate companies active in the commercial sector. Finland provides an interesting case as the Finnish listed companies ranked the highest for the quality of the measurement and reporting of the CSR among the world's stock exchanges in the year 2014 (Mitopro, 2014). The rational for focusing on commercial sector is due to its significant influence on surrounding society's economics, environment, politics, community and culture (Toivonen \& Viitanen, 2016). Meanwhile, the surrounding society, its stakeholders and 
various forces of change, such as environmental pressure, have their own influence on the commercial sector and its future development (Toivonen \& Viitanen, 2016). The reason for sampling listed companies is that Nasdaq Helsinki Stock Exchange recommends its listed companies to include basic CSR data in their annual reports (Corporate Knights, 2014). Majority of the non-listed real estate companies in Finland do not publish sustainability reports and only possibility to assess their sustainability performance is to conduct interviews, which is out of this study's scope.

In order to explore the list of the listed companies, the Finnish Property Market Report 2016 (KTI, 2016) was used. In total, eight real estate companies were identified with the above-mentioned specifications. The selected companies' scope of activities covers the Nordic region. Among the 30 biggest real estate investment companies in Finland, there are three companies listed on the main list of the Helsinki Stock Exchange. Among the wide range of construction companies active in commercial property development in Finland, five construction companies are listed either in Helsinki or in Stockholm Stock Exchange. Besides their considerable financial performance, the selected companies are ranked highest for their best practices in environmental responsibility and sustainability on Green Building Council Finland.

The preliminary analysis showed that the selected companies employ a variety of channels to communicate with their stakeholders, including annual reports, sustainability booklets, interim reports, websites, and building brochures. Authors decided to collect data from annual reports, sustainability booklets, interim reports, websites, and building brochures. To avoid the uncertainties in relying only on annual reports (see Adams \& Harte, 1998; Roberts, 1991), the other communication channels were selected to provide a more comprehensive picture of each company's sustainability reporting practices. Therefore, in our study, 34 documents were collected for analysis, including eight annual reports, two sustainability booklets, eight quarter-II 2014 interim reports, eight website contents and eight building brochures. The collected documents hereinafter referred to as "sustainability reports".

To assist the data analysis, the authors used a computer-assisted qualitative data analysis software: MAXQDA 11. All parts of the written texts prior to the financial statements were included in the analysis. Before developing the content analysis structure, initial research was performed to realise the characteristics of the sustainability reports and identify the most complied reporting framework by the sample companies. These findings are presented in the next subsection.

\subsubsection{Sustainability reports: form, size, structure, and frameworks}

Among the eight companies, only one issued a stand-alone sustainability report while the other seven published their corporate sustainability disclosure as part of their annual reports. The size of the sustainability reports varied from few pages on general aspects of sustainability, to a detailed set of sustainability information that was in reasonable balance with the financial statement. With respect to the structure of the sustainability reports, the majority of the reports had the following sections: "Introduction", "Aims and values", "Organization profile", "Performance", "Reporting principles and boundaries", and "Comparison of the report with the reporting guidelines". The focal point of the reports could be categorised in three groups: communication aspects with investors and other stakeholders, monitoring aspects of social and environmental impacts, and internal aspects of a business.

The collected sustainability reports were compiled with diverse reporting frameworks; including GRI, GRESB and EPRA ${ }^{1}$. However, there was one company that did not mention whether they comply with any sustainability reporting framework. From eight sample companies, six employed GRI G3 or G3.1 Construction and Real Estate Sector Supplement [CRESS] index - as a framework for their sustainability reports. Only one company reported its sustainability information in accordance with GRI G4 CRESS index. Based on the six corporate self-assessments, the reports represented GRI Application Levels from Level C to Level B+.

In addition, three companies reported their sustainability reports based on EPRA Sustainability Best Practices recommendations. Two companies also participated in GRESB surveys, which is sent to the member real estate companies on an annual basis and it assesses the Environmental, Social and Corporate governance (ESG) performance of their portfolios and infrastructure assets. Out of the eight companies, three received awards for their sustainability reports in 2013, including a Bronze award from EPRA, a GRESB second Green Star award, and the award "Best construction company in the Nordic countries at reporting carbon emissions" awarded by CDP's Nordic 260 Climate Disclosure Leadership index.

\subsection{Content analysis process and coding system}

To assess the content of sustainability reports, our study applied a content analysis method and developed a coding system. The content analysis process in our study consisted of two tasks: 1) Quantity of information - based on GRI G4 CRESS index; and 2) Quality of information derived from Vuontisjärvi (2006).

One of the aims of the content analysis is to read documents several times in order to become immersed in the data (Hsieh \& Shannon, 2005). In our study, content analysis started with reading the collected documents first as one would read a novel. Later, authors re-read each document for several times in order to explore the content of the given data by using the coding system.

\footnotetext{
1 Detailed findings on the frameworks of the sustainability reporting compilation are presented in Table I and Figure I in the Supplementary Appendix 1.
} 
The review of the previous studies investigated sustainability reports in the real estate sector shows that content analysis has precedence in the real estate-related research (for example Chen et al., 2016; Zuo, Zillante, Wilson, Davidson, \& Pullen, 2012; Glass, 2012; Willetts et al., 2011; T. Jones et al., 2010; Myers, 2005). Krippendorff (2004) has defined content analysis as 'a research technique for making replicable and valid inference from texts to the context of their use. Since this research aims to make inferences about the real estate corporate sustainability reporting practices based on public documents, content analysis was considered as a suitable means for quantifying and qualifying the sustainability information issues by the sample companies.

Some researchers (see Beattie \& Thomson, 2007; Striukova, Unerman, \& Guthrie, 2008), however, have criticised that many studies, which applied content analysis, lack sufficient information to enable replication of the study. To avoid such a problem, the following subsections describe the process of content analysis and coding system under each task in details.

\subsubsection{Task 1: quantity of information}

In task 1, the theoretical framework of the research was developed and the coding system for quantitative analysis formulated based on the latest version of GRI framework; G4 CRESS index (see Figure 1).

A comprehensive content analysis demands that a coding system is derived from the shared concepts (Beattie \& Thomson, 2007; Gray, Kouhy, \& Lavers, 1995). Our preliminary findings show that GRI CRESS index serves as an appropriate basis for developing our coding system, as it is the most common framework applied by the sample companies. The reason for choosing the most updated version was that the sample companies are required to comply with this framework in the near future, and our study provides a basis to reflect what aspects in sustainability reporting are missing or need further improvements, in advance.

The GRI G4 CRESS index demands companies to focus on the topics that are material to their field of activity and to their stakeholders. The structure of the index is a hierarchical form and consists of two areas: General Standard Disclosures and Specific Standard Disclosures. General Standard Disclosures covers information related to the corporate governance theme. Specific Standard Disclosures covers economic, environmental, and social responsibility themes. Each theme of the Specific Standard Disclosures includes a set of codes. The social responsibility codes also contain a set of sub codes. Our study only considered the Specific Standard Disclosures' themes for content analysis. To conduct task 1 (quantity of information), each sustainability report was codified sentence by sentence and frequency of each code (the rate at which codes are repeated in a given sample) was calculated.
Quantity of information

\begin{tabular}{|c|c|}
\hline \multicolumn{2}{|c|}{ Specific Standard Disclosures } \\
\hline \multicolumn{2}{|c|}{$\begin{array}{l}\text { Theme - Economic Responsibility } \\
\text { Code - Economic Performance } \\
\text { Market Presence } \\
\text { Indirect Economic } \\
\text { Procurement Practices }\end{array}$} \\
\hline \multicolumn{2}{|c|}{$\begin{array}{l}\text { Theme - Environmental Responsibility } \\
\text { Code - Materials } \\
\text { Energy } \\
\text { Water } \\
\text { Biodiversity } \\
\text { Emissions } \\
\text { Efluents and Waste } \\
\text { Products and Services } \\
\text { Compliance } \\
\text { Transport } \\
\text { Overall } \\
\text { Supplier Environmental Assessment } \\
\text { Environmental Grievance Mechanisms } \\
\text { Land Degradation, Contamination and Remediation }\end{array}$} \\
\hline $\begin{array}{r}\text { Theme - Social Responsibility } \\
\text { Code - Labour Practi } \\
\text { Sub-code - }\end{array}$ & $\begin{array}{l} \\
\text { ices and Decent Work } \\
\text { Employment } \\
\text { Labour/Management Relations } \\
\text { Occupational Health and Safety } \\
\text { Training and Education } \\
\text { Diversity and Equal Opportunity } \\
\text { Equal Remuneration for Women and Men } \\
\text { Supplier Assessment for Labour Practices } \\
\text { Labour Practices and Grievance Mechanisms }\end{array}$ \\
\hline $\begin{array}{c}\text { Code - Human Right } \\
\text { Sub-code - } \\
\text { Sul }\end{array}$ & $\begin{array}{l}\text { ts } \\
\text { Investment } \\
\text { Non-discrimination } \\
\text { Freedom of Association and Collective Bargaining } \\
\text { Child Labour } \\
\text { Forced or Compulsory Labour } \\
\text { Security Practices } \\
\text { Indigenous Rights } \\
\text { Assessment } \\
\text { Supplier Human Rights Assessment } \\
\text { Human Rights Grievance Mechanisms }\end{array}$ \\
\hline $\begin{array}{l}\text { Code - Society } \\
\text { Sub-code - }\end{array}$ & $\begin{array}{l}\text { Local Communities } \\
\text { Anti-corruption } \\
\text { Public Policy } \\
\text { Anti-Competitive Behaviour } \\
\text { Compliance } \\
\text { Supplier Assessment for Impacts on Society } \\
\text { Grievance Mechanisms for Impacts on Society }\end{array}$ \\
\hline $\begin{array}{c}\text { Code - Product Resp } \\
\text { Sub-code - }\end{array}$ & $\begin{array}{l}\text { onsibility } \\
\text { Customer Health and Safety } \\
\text { Product and Service Labeling } \\
\text { Marketing Communications } \\
\text { Customer Privacy } \\
\text { Compliance }\end{array}$ \\
\hline
\end{tabular}

Figure 1. Coding system - Quantity of information based on GRI G4 CRESS index

\subsubsection{Task 2: quality of information}

The second task of our study distinguishes between three information types derived from Vuontisjärvi (2006), and are: 1) Sustainability aims and values, 2) Sustainability measures and practices, and 3) Qualitative and quantitative sustainability performance data (see Figure 2).

Several scholars have suggested that covering different types of information allows companies to reflect a comprehensive picture of their impact and performance (see Adams, 2004; Hooks \& Van Staden, 2007; Robertson \& Nicholson, 1996; Vuontisjärvi, 2006). This in turn may lead to a greater transparency and higher reputational capital. 
Quality of information

\begin{tabular}{|l|l|}
\hline Information types & \\
Theme - Economic Responsibility & $\begin{array}{l}\text { 1. Aims and values } \\
\text { 2. Measures and practices } \\
\text { 3. Qualitative and quantitative performance data }\end{array}$ \\
Theme - Environmental Responsibility & $\left\{\begin{array}{l}\text { 1. Aims and values } \\
\text { 2. Measures and practices } \\
\text { 3. Qualitative and quantitative performance data }\end{array}\right.$ \\
Theme - Social Responsibility $\left\{\begin{array}{l}\text { 1. Aims and values } \\
\text { 2. Measures and practices } \\
\text { 3. Qualitative and quantitative performance data }\end{array}\right.$ \\
\hline
\end{tabular}

Figure 2. Coding system - Quality of information based on Vuontisjärvi (2006)

As well as Vountisjärvi's (2006) proposed information types to analyse Human Resource reporting by Finnish companies, other researchers also have developed different categories to analyse information types in reports. For instance, Cormier and Magnan (2007), in their study on corporate environmental reporting, assigned codes and weights to documents based on the available information types. The highest weight category $(+3)$ included quantitative or general disclosure, the middleweight category $(+2)$ was given to documents that had non-quantitative but specific disclosures, and the lowest weight category $(+1)$ was assigned to general qualitative disclosures. Bouten, Everaert, Van Liedekerke, De Moor, and Christiaens (2011) took advantage of content analysis in their assessment of the corporate social responsibility reports of Belgian companies. The developed content analysis framework by Bouten et al. could identify the codes, and divide them into three information types: 1 . Vision and goals; 2. Management approach; 3. Performance indicators.

To perform task 2 of our study (quality of information), each sustainability report was coded sentence by sentence based on three defined information types to explore the quality of information provided for each theme, be they economic, environmental, and social responsibility.

\subsection{Validity and reliability}

After conducting content analysis, authors should demonstrate the validity and reliability of their instruments and the collected data to allow replicable and valid inferences to be drawn from the findings (Guthrie \& Abeysekera, 2006). In order to comply with this, first, to indicate the validity of the coded dataset, two trained coders were employed for content analysis. The discrepancies between coders' dataset were negligible. Second, the validity of the findings was tested by content validity. The sample companies were contacted to confirm whether the collected documents represent the comprehensive picture of their corporate sustainability reporting practices. All the companies confirmed.

To increase the reliability in analysing data Beattie and Thomson (2007) and Guthrie, Boedker, and Cuganesan (2004) have suggested to select coding categories from well-grounded relevant literature. Therefore, the coding categories for our study were derived from GRI, which is the most well-known and most-utilised reporting framework among companies in the Europe (KPMG, 2015; Andelin et al., 2013). In addition, the reliability of the findings was tested through parallel forms reliability technique, in which two different sets of codes, including GRI G4 CRESS and Responsible Property Investment criteria (UNEP FI Property Working Group, 2008), were applied to test if the results are parallel. The distribution of codes under each theme in both systems were consistent. Based on these techniques, it seems that the distribution of the codes could be consistent in other reporting frameworks, such as EPRA or GRESB.

After demonstrating the reliability and validity of the content analysis process, the results were interpreted for further discussion and are presented in section 4 .

\section{Findings and discussion}

This section describes the findings obtained from the content analysis process. Our results show a lack of a consistent approach to sustainability reporting in the real estate sector. The majority of the sample companies preferred to issue their sustainability reports merged with their annual reports instead of stand-alone disclosures. Seven out of eight sample companies followed international reporting guidelines in issuing their sustainability reporting. Majority of the sustainability reports were complied with GRI CRESS index. However, among the sample companies, 
only a minority have included some form of external assurance or embraced materiality concept as part of their sustainability reporting practices.

In addition to GRI CRESS index, all the three real estate investment companies applied EPRA recommendations, for the sake of their membership in EPRA group. Two out of the three investment companies also participated in GRESB surveys. Our results show that the majority of the sample companies recognised the effectiveness of employing websites as a communication platform for providing updated sustainability information to the public, in order to promote their stakeholder relations and gain higher reputation.

By performing content analysis for identifying quantity of information (task 1), 3939 codes were found within the sustainability reports. Out of which, 838 belonged to economic responsibility theme, 949 to environmental responsibility, and 981 to the social responsibility theme. A detailed overview on the quantity of the information related to economic, environmental, and social responsibility themes is presented in Table II and Figure II in the Supplementary Appendix 2. The distribution of the codes in a relatively consistent form among the three themes raises questions about the reason behind it. One reason could be that companies have embraced sustainability reporting in a holistic way, or could this be a greenwashing?

In total, $30 \%$ of the sustainability reports were covered with economic-related information. The selected companies addressed a variety of economic issues, which can be found with more details in Figure III in the Supplementary Appendix 2. Economic performance was the most frequent code under economic responsibility theme, repeated 660 times.

Information related to the sustainability measures and practice (information type 2) was the most common type of the information seen for the economic-related information. This is mainly because of the Accounting Act $(1336 / 1997)$ in Finland that requires companies to provide accurate and sufficient information about the return on their business activities. In addition, all of the companies in the sample provided information on the corporate tax expenses and impacts both in their annual and interim reports. These efforts were made to contribute to higher transparency and reliability.

Environmental-related information covered $34 \%$ of the sustainability reports. A variety of environmental issues was addressed by sample companies (see Figure IV in the Supplementary Appendix 2 for further details). The most repeated codes were energy (252 times); effluents and waste (114 times); emissions (104 times); materials (85 times); and water (75 times). On the other hand, the lack of information on the suppliers' environmental impact was observed in the sustainability reports, which is against the recommendations of the GRI G4 CRESS index.

Most of the environmental-related information belonged to sustainability measures and practices (informa- tion type 2). Yet, all the three information types were issued in the following: energy, water, waste, and emissions. The performance data for the previously-mentioned codes were also presented in quantitative form in some of the sustainability reports. Extensive coverage of environmental-related issues, especially energy, waste and emissions, is due to the negative impact of real estate on climate change and the environment. To address this challenge, Finnish Government and the EU have approved strict regulatory requirements that could cause financial or legal risks to companies if not followed. Therefore, our results propose that environmental pressure has become one of the most significant forces of change in the real estate markets, as Toivonen (2011) and Toivonen and Viitanen $(2015,2016)$ discussed in their work.

Social-related information was the most common theme recognised in the sustainability reports with $36 \%$ coverage. The sample companies dedicated a major part of their social-related information on the labour practice and decent work (426 times) and product responsibility (257 times) issues (see Figure V in the Supplementary Appendix 2 for more details).

Labour practice and decent work code consists of several sub codes. Among those, employment, occupational health and safety, and training and education were the most addressed matters. Employment issues were addressed by companies to fulfil the Employment Contracts Act (55/2001). Extensive coverage of occupational health and safety, and training and education were mostly seen in the construction companies' sustainability reports. This is mainly because construction sector in particular is prone to physical risks and hazards.

Among three types of the information, qualitative and quantitative sustainability performance data (information type 3) was the most common type seen in the reports, especially in the case of occupational safety and healthrelated matters. This is mainly due to compliance with Occupational Safety and Health Act (738/2002). On the other hand, sample companies gave less attention to human rights among social-related themes. This is possibly because cases of human rights violations are rare in Nordic countries. Whenever human-rights related information was reported in a sustainability report, it targeted the corporate international suppliers.

Analysis for assessing the quality of the information (task 2) revealed that $34 \%$ of the codes appeared in the GRI G4 CRESS index discussed about the aims and values of the sample companies (information type 1), $40 \%$ of the codes were about undertaken sustainability measures and practices of the sample companies (information type 2 ), and $26 \%$ of the codes provided qualitative or quantitative performance indicators of the sample companies (information type 3). Table III and Figures VI and VII in the Supplementary Appendix 2 provide the detailed description of the types of information related to economic, environmental and social responsibility themes. 
The findings of our study show that most of the companies described their sustainability practices to some extent, but failed to present their performance indicators in qualitative and quantitative forms for environmental and social responsibility themes. None of the companies reported all the three information types, including 1) Sustainability aims and values, 2) Sustainability measures and practices, and 3) Qualitative and quantitative sustainability performance data; for the entire GRI G4 CRESS index codes.

In addition, shortcomings were identified in the context of materiality and external assurance. Although it seems that some of the sample companies have adopted the concept of materiality matrix, proposed by the GRI, they mainly focused on the impacts that affect their business activities, rather than their surrounding environment. One useful approach to determine the material issues in sustainability reporting practices, is to engage stakeholders (P. Jones et al., 2016). However, our findings suggest that in the sample companies, material issues were identified and determined mainly by the corporate decision-makers. Whether the stakeholders' opinions were comprehensively collected, analysed and integrated in determining those material issues, remains unaddressed within the studied reports.

Previous research shows that external assurance of sustainability reports has become an important factor for a wide range of stakeholders, especially investors, and policymakers (P. Jones et al., 2015, 2016). However, commissioning external assurance for sustainability information was very limited in our sample. The reason could be that the collection and provision of data across a wide range of business activities in different countries, as well as supply chain, is a financially demanding process, thus, many companies choose not to commission external assurance. However, the lack of independent external assurance can decrease the integrity and credibility of the sustainability reporting processes. These findings are in line with those of Jones, P. et al. $(2015,2016)$ and Willetts et al. (2011).

If the practice of sustainability reporting is compared based on the business area of the sample companies, our results demonstrate that the real estate investment companies had a more systematic approach to sustainability reporting than construction companies. The reason could be that all the real estate investment companies are members of EPRA. EPRA has developed a clear sustainability Best Reporting Practices (BPR) and guidance upon GRI G4 CRESS for its members and require them to follow it.

Our findings suggest that companies reported only the information that they already gathered for internal purpose or reported mostly on the issues that they were best in. Therefore, that is the reason none of the sustainability reports could cover all the recommended codes in GRI G4 CRESS.

Previous literature suggests three motivation factors for issuing sustainability information, including: 1) to improve stakeholder engagement and gain reputational capital, 2) to avoid legal and financial risks, and 3) to address policies, society, or non-governmental organisations' demand. Our findings suggest that most of the companies issued sustainability information under compulsion, either to avoid the financial and legal risks (factor 2) due to enforcement of local legislations or introduction of EU Directive 2014/95/EU: Disclosure of non-financial and diversity information in 2017; or to fulfil the requirements of the Stock Exchange or EPRA requirements (factor 3). Our results confirm a lack of systematic approach to improve the communication with the stakeholders and engage them into the decision-making process (factor 1). This means that sample companies have not yet recognised the link between reputational capital, improved stakeholder engagement and higher quality of reports as described by Brown, D. L. et al. (2009) theory in section 1 of this paper.

\section{Conclusion}

The aim of our study was to investigate the content of sustainability reports in the real estate companies. This aim was achieved by identifying the strengths and challenges around sustainability reports issued by Nordic real estate companies, using empirical evidence from Finland. To address this aim, content analysis was applied to analyse the sustainability information presented in communication channels of real estate companies. The content analysis structure was arranged by such a manner that in addition to analysing the quantity of the information; it gave an overview of the quality of information. This knowledge was not available in the national-context, when the analysis started.

GRI G4 CRESS index and Vuontisjärvi's information type classification were useful references for codifying the text, covering all the data given in the sustainability reports. It was interesting to see that the GRI G4 CRESS index has provided more detailed codes for environmental and social responsibility themes than for economic responsibility theme. The reason could be that real estate companies are fully aware of the content required to be provided for economic responsibility (financial reports) due to the nature of the companies, but this knowledge is missing in the fields of environmental and social responsibility and that is why more codes are provided for those themes.

Our results indicate that the approach to, and extent of issuing sustainability information are diverse among the sample companies. The majority of the sample companies tended to provide narrative non-assured sustainability information, lacking performance indicators. Over $74 \%$ of the reported information were not in the form of detailed qualitative or quantitative performance data (information type 3). Lacking performance indicators and external assurance can decrease the level of corporate credibility in the eyes of stakeholders and generate suspicion about the reliability of the information provided. In addition to the mentioned challenges, our findings recognise a lack of a systematic approach to engage stakeholders in defining 
material issues in corporate sustainability reporting processes. Our findings are in line with the majority of previous literature reviewed in section 2 (see P. Jones et al., 2016, 2015; Andelin et al., 2015, 2013; Glass, 2012; Willetts et al., 2011).

None of the sample companies could address all the recommended codes in the GRI G4 CRESS index. The sample companies showed a higher propensity to report on the following codes: economic performance $(660$ times), energy (252 times), and labour practice and decent work (426 times). Economic-related issues were mainly reported to address the Accounting Act (1336/1997) requirements. Environment - related information were issued to reduce the potential legal and financial risks caused by strict environmental regulatory requirements approved in Finland and the EU. Information on Labour practice and decent work was given to comply with the Employment Contract Act (55/2001), and Occupational Safety, and Health Act (738/2002). Our findings suggest that the strongest motive for companies to engage in sustainability reporting issuance is to fulfil the legislative requirement to avoid any financial or legal risks. Based on our findings, it can be concluded that the potential of increasing business benefits through improved stakeholder engagement and higher quality of reports, as described by Brown, D. L. et al. (2009), is not still recognised by the sample companies.

The results of our study should be treated with an appropriate care, taking into account the size of the sample. In addition, selecting listed commercial real estate companies with the best sustainability practices for our study, does not allow drawing conclusions about the sustainability reporting behaviour of non-listed companies in the commercial sector. Thus, the overall behaviour of the commercial sector towards sustainability reporting could be even weak, if those non-listed companies were included in the sample. However, the majority of the non-listed companies in Finland do not publish sustainability reports and only possibility to assess their sustainability performance is to conduct interviews. Furthermore, the majority of sustainability reports were not audited by a third party. There could be a possibility that some companies overestimated their performance in their reports.

From the methodological perspective, there are also limitations in the use of content analysis. First limitation is that it usually captures quantity of discloser (frequency and volume of reporting) rather than quality (Guthrie \& Abeysekera, 2006). Second limitation is the subjective nature of content analysis, in a way that it captures various narratives as a representation of sustainability performance (Guthrie \& Abeysekera, 2006). In order to address the first limitation, we developed a combined content analysis to capture both the quantity and quality of the sustainability information. To address the second limitation, reliability of both data and the coding structure was achieved as discussed in subsection 3.4. Furthermore, content analysis does not allow 'reception studies, in which corporate stakeholders' perception of sustainability reports is studied. Therefore, potential future research on the stakeholders' perception could provide a greater understanding to the materiality issues that should be addressed in the sustainability reports. Other potential future study can investigate sustainability reporting practices issued by non-listed commercial real estate companies or companies active in other real estate sectors for presenting an overall picture of the Nordic real estate sector. Further extension of our study could be to explore whether specific GRI themes, or GRI application levels (A, B, and $\mathrm{C}$ ), or commissioning external assurance are more valued by investors.

The findings achieved by content analysis could be regarded as a good overview of the current best sustainability reporting practices in the commercial real estate sector in the Nordic context, as the scope of the sample corporate activities moves beyond Finland and covers the Nordic region. In addition, the novelty of our study is that it employs a combined content analysis to capture both the quantity and quality of the sustainability information and across two real estate sectors. This approach caused the evaluation of sustainability information to be more comprehensive, precise and effective. Such structure can be employed by listed companies as a checklist to develop their sustainability reports in accordance with requirements of mandatory reporting legislation that will be introduced by the EU Directive on non-financial and diversity information in 2017.

Currently, sustainability reporting has become a significant topic and previous studies have shown the weaknesses of sustainability reporting in other countries. Based on the theories mentioned in section 1 , there is a correlation between the quality of the reports and the corporate reputational capital. The findings of our study can be used by real estate sustainability analysts for identifying the shortcomings of their corporate sustainability reports and take action to tackle the challenges. If so, they can avoid the relevant financial and legal risks, and increase the level of their corporate reputational capital. This in the longer term can also contribute in promoting sustainable development in the real estate sector.

Our study contributes to the extant literature by discussing the usability of the stakeholder theory in the context of sustainability reporting. Another theoretical contribution of our study is identifying the motivation factors, extent and quality of corporate sustainability reports in the Nordic context. These proved to be the main themes in the extant literature on global level, however, was not studied in the Nordic context before. In addition, our study contributes to the existing literature by providing evidence for using a combined structure of content analysis to capture both the quantity and quality of the sustainability information. This approach helps researchers to overcome the limitation of content analysis in capturing quality of disclosers. 


\section{References}

Accounting Act. 1336/1997. Retrieved from http://www.finlex.fi/ en/laki/kaannokset/1997/en19971336

Adams, C. A. (2004). The ethical, social and environmental reporting-performance portrayal gap. Accounting, Auditing \& Accountability Journal, 17, 731-757. https://doi.org/10.1108/09513570410567791

Adams, C. A., \& Harte, G. (1998). The changing portrayal of the employment of women in British banks' and retail companies' corporate annual reports. Accounting, Organisations and Society, 23(8), 781-812.

https://doi.org/10.1016/S0361-3682(98)00028-2

Andelin, M., Kyrö, R., \& Sarasoja, A. L. (2013). Current sustainability reporting practices in Nordic real estate companies. Proceedings of the Pacific Rim Real Estate Society $19^{\text {th }}$ Annual Conference, 13-16 January 2013. Melbourne, Australia.

Andelin, M., Sarasoja, A. L., Ventovuori, T., \& Junnila, S. (2015). Breaking the circle of blame for sustainable buildings-evidence from Nordic countries. Journal of Corporate Real Estate, 17(1), 26-45. https://doi.org/10.1108/JCRE-05-2014-0013

Aras, G., \& Crowther, D. (2009). Corporate sustainability reporting: a study in disingenuity?. Journal of Business Ethics, 87(6), 279-289. https://doi.org/10.1007/s10551-008-9806-0

Beattie, V., \& Thomson, S. J. (2007). Lifting the lid on the use of content analysis to investigate intellectual capital disclosures. Accounting Forum, 31, 129-163. https://doi.org/10.1016/j.accfor.2007.02.001

Bizzari, K. (2013). Refusing to be accountable. Corporate Europe Observatory. Retrieved from https://corporateeurope.org/sites/ default/files/publications/refusing_to_be_accountable.pdf

Bouten, L., Everaert, P., Van Liedekerke, L., De Moor, L., \& Christiaens, J. (2011). Corporate social responsibility reporting: a comprehensive picture?. Accounting Forum, 35, 187204. https://doi.org/10.1016/j.accfor.2011.06.007

Brown, D. L., Guidry, R. P., \& Pattern, D. M. (2009). Sustainability reporting and perceptions of corporate reputation: an analysis using fortune. In M. Freedman \& B. Jaggi, (Eds.), Vol. 4 - Sustainability, environmental performance and disclosures. Book series: Advances in environmental accounting \& management (pp. 83-104). Emerald Group Publishing Limited.

Brown, J., Parry, T., \& Moon, J. (2009). CR reporting in UK construction. Proceedings of the Institution of Civil Engineering Sustainability, 162 (ES4), 193-205.

https://doi.org/10.1680/ensu.2009.162.4.193

Brundtland Commission. (1987). Our Common Future. World Commission on Environment and Development. Oxford: Oxford University Press.

Burson-Marsteller. (2003). Non-governmental organizations seek more candor incorporate social responsibility reports. Retrieved from www.bursonmarsteller.com/newsroom/lists/PressReleases

Byrch, C., Kearins, K., Milne, M. J., \& Morgan, M. K. (2007). Sustainable 'what'? A cognitive approach to understanding sustainable development. Qualitative Research in Accounting and Management, 4(1), 26-52. https://doi.org/10.1108/11766090710732497

Caijas, M., Geiger, P., \& Bienert, S. (2012). Green agenda and green performance: empirical evidence for real estate companies. Journal of European Real Estate Research, 5(2), 135-155. https://doi.org/10.1108/17539261211250717

Carnevale, C., \& Mazzuca, M. (2014). Sustainability report and bank valuation: evidence from European stock markets. Business Ethics: A European Review, 23(1), 69-90. https://doi.org/10.1111/beer.12038
Carrots \& Sticks. (2016). Global trends in sustainability reporting regulation and policy. Retrieved from http://www.carrotsandsticks.net/wp-content/uploads/2016/05/Carrots-Sticks-2016.pdf

Chen, P. H., Ong, C. F., \& Hsu, S. C. (2016). Understanding the relationships between environmental management practices and financial performance of multinational construction firms. Journal of Cleaner Production, 139, 750-760.

https://doi.org/10.1016/j.jclepro.2016.08.109

Cho, C. H., Patten, D. M. (2007). The role of environmental disclosures as tools of legitimacy: a research note. Accounting, Organizations and Society, 32(7/8), 639-647.

https://doi.org/10.1016/j.aos.2006.09.009

Cormier, D., \& Magnan, M. (2007). The revisited contribution of environmental reporting to investors' valuation of a firm's earnings: an international perspective. Ecological Economics, 62, 613-626. https://doi.org/10.1016/j.ecolecon.2006.07.030

Corporate Knights. (2014). Taking stock. Retrieved from http:// www.corporateknights.com/channels/responsible-investing/ taking-stock-14132754/

Crowther, D. (2003). Social responsibility and the marketization of higher education. Staff and Educational Development International, 7(1), 23-40.

Deegan, C. M. (2002). Introduction: the legitimising effect of social and environmental disclosures - a theoretical foundation. Accounting, Auditing and Accountability Journal, 15(3), 282-311. https://doi.org/10.1108/09513570210435852

Elkington, J. (2004). Enter the triple bottom line. In A. Henriques \& J. Richardson (Eds.), The triple bottom line, does it all add up? Assessing the sustainability of business and CSR (pp. 1-16). London: Earthscan Publications.

Employment Contracts Act 55/2001. Retrieved from http://www. expat-finland.com/pdf/employment_contracts_act.pdf

Epstein, M. J., \& Freedman, M. (1994). Social disclosure and the individual investor. Auditing \& Accountability Journal, 7(4), 94-109. https://doi.org/10.1108/09513579410069867

European Commission. (2016). Non-Financial Reporting. Retrieved from http://ec.europa.eu/finance/company-reporting/ non-financial_reporting/index_en.htm

Glass, J. (2012). The state of sustainability reporting in the construction sector. Smart and Sustainable Built Environment, 1(1), 87-104. https://doi.org/10.1108/20466091211227070

Gray, R., Kouhy, R., \& Lavers, S. (1995). Methodological themes: constructing a research database of social and environmental reporting by UK companies. Accounting, Auditing \& Accountability Journal, 8(2), 78-101.

https://doi.org/10.1108/09513579510086812

Gray, R., Owen, D., \& Adams, C. (2015). Some theories for social accounting?: a review essay and a tentative pedagogic categorisation of theorisations around social accounting. Sustainability, Environmental Performance and Disclosures, 4, 1-54.

GRI. (2013). GRI, G4 sustainability reporting guidelines: reporting principles and standard disclosures. Global Reporting Initiative, Amsterdam. Retrieved from https://www.globalreporting.org/resourcelibrary/GRIG4-Part1-Reporting-Principlesand-Standard-Disclosures.pdf

Group of 100. (2004). Sustainability reporting: a guide. Melbourne, Australia: KPMG.

Guthrie, J., \& Abeysekera, I. (2006). Content analysis of social, environmental reporting: what is new?. Journal of Human Resource Costing and Accounting, 10(2), 114-126. https://doi.org/10.1108/14013380610703120

Guthrie, J., Boedker, C., \& Cuganesan, S. (2004). Final report: Department of Lands, NSW, Management, Measurement and Reporting of Intellectual Capital. Report of MGSM Centre for the Management of Knowledge Capital, December, Sydney. 
Higgins, C., \& Coffey, B. (2016). Improving how sustainability reports drive change: a critical discourse analysis. Journal of Cleaner Production, 136, 18-29.

https://doi.org/10.1016/j.jclepro.2016.01.101

Higgins, C., Milne, M., \& van Gramberg, B. (2015). The uptake of sustainability reporting in Australia. Journal of Business Ethics, 129(2), 445-468.

https://doi.org/10.1007/s10551-014-2171-2

Hockerts, K. (2015). A cognitive perspective on the business case for corporate sustainability. Business Strategy Environment, 24(2), 102-122. https://doi.org/10.1002/bse.1813

Hooks, J., \& Van Staden, C. J. (2007). The corporatization and commercialization of local body entities: a study of financial performance. ABACUS, 43, 217-240.

https://doi.org/10.1111/j.1467-6281.2007.00226.x

Hsieh, H. F., \& Shannon, S. E. (2005). Three approaches to qualitative content analysis. Quality Health Research, 15(9), 12771288. https://doi.org/10.1177/1049732305276687

Idowu, S. O., \& Towler, B. A. (2004). A comparative study of the contents of corporate social responsibility reports of UK companies. Management of Environmental Quality: An International Journal, 15, 420-437.

https://doi.org/10.1108/14777830410540153

Ioannou, I., \& Serafeim, G. (2011). The consequences of mandatory corporate sustainability reporting. Harvard Business School Working Paper No. 11-100, Boston, MA: Harvard University.

Jones, P., Comfort, D., \& Hillier, D. (2006). Corporate social responsibility and the UK construction industry. Journal of Corporate Real Estate, 8(3), 134-150.

https://doi.org/10.1108/14630010610711757

Jones, P., Comfort, D., \& Hillier, D. (2015). Materiality and external assurance in corporate sustainability reporting: an exploratory study of UK house builders. Property Management, 33(5), 430-450. https://doi.org/10.1108/PM-03-2015-0014

Jones, P., Hillier, D., \& Comfort, D. (2016). Materiality and external assurance in corporate sustainability reporting: an exploratory study of Europe's leading commercial property companies. Journal of European Real Estate Research, 9(2), 147-170. https://doi.org/10.1108/JERER-07-2015-0027

Jones, T., Shan, Y., \& Goodrum, P. M. (2010). An investigation of corporate approaches to sustainability in the US engineering and construction industry. Construction Management and Economics, 28(9), 971-983.

https://doi.org/10.1080/01446191003789465

Jose, P. D., \& Saraf, S. (2016). Corporate sustainability initiatives reporting: a study of India's most valuable companies. In P. D. Jose (Ed.), Corporations and sustainability: the South Asian perspective (pp. 49-89). Sheffield: Greenleaf Publishing Limited. https://doi.org/10.9774/GLEAF.9781783530854_5

Kajander, J.-K., Sivunen, M., Vimpari, J., \& Junnila, S. (2012). Market value of sustainability business innovations in the construction sector. Building Research and Information, 40(6), 665-678. https://doi.org/10.1080/09613218.2012.703893

Kaspereit, T., \& Lopatta, K. (2016). The value relevance of SAM's corporate sustainability ranking and GRI sustainability reporting in the European stock markets. Business Ethics-A European Review, 25(1), 1-24.

https://doi.org/10.1111/beer.12079

KPMG. (2015). Currents of change - the KPMG survey of corporate responsibility reporting 2015. The Netherlands: KPMG.

Krippendorff, K. (2004). Conceptual foundation, in Content analysis - an introduction to its methodology (pp. 18-21). London: Sage Publications.
KTI. (2016). Finnish property market 2016. KTI Finland, Helsinki. Retrieved from http://kti.fi/wp-content/uploads/TheFinnish-Property-Market-2016.pdf

Lourenco, I., Branco, M., Curo, J. D., \& Eugenio, T. (2012). How does the market value corporate sustainability performance? Journal of Business Ethics, 108(4), 417-428.

https://doi.org/10.1007/s10551-011-1102-8

Milne, M. J., \& Gray, R. J. (2013). W(h)ither ecology? The triple bottom line, the global reporting initiative, and corporate sustainability reporting. Journal of Business Ethics, 118(1), 13-29. https://doi.org/10.1007/s10551-012-1543-8

Mitopro. (2014). Suomalaisyhtioiden yritysvastuun mittaaminen ja raportointi hipputasolla (in Finnish). Retrieved from http:// www.mitopro.fi/suomalaisyhtioiden-raportointi-huipputasolla/

Muhammad, Z., Zulkipli, C., \& Haseeb, Ur. R. (2016). Corporate sustainability practices \& reporting: a case of Malaysian REITs and property listed companies. International Journal of Economics and Financial Issues, 6(2), 688-693.

Myers, D. (2005). A review of construction companies' attitudes to sustainability. Construction Management and Economics, 23(8), 781-785. https://doi.org/10.1080/01446190500184360

O’Dwyer, B., Unerman, J., \& Hession, E. (2005). User needs in sustainability reporting: perspectives of stakeholders in Ireland. European Accounting Review, 14, 759-787.

https://doi.org/10.1080/09638180500104766

Occupational Safety and Health Act 738/2002. Retrieved from http://www.finlex.fi/en/laki/kaannokset/2002/en20020738.pdf

Okoye, A. (2009). Theorising corporate social responsibility as an essentially contested concept: is a definition necessary?. Journal of Business Ethics, 89, 613-627.

https://doi.org/10.1007/s10551-008-0021-9

Paton, G. J. (2010). Seeking sustainability: on the prospect of an ecological liberalism. London: Routledge.

Pearce, A. R., \& Vanegas, J. A. (2002). Defining sustainability for built environment systems: an operational framework. International Journal of Environmental Technology and Management, 2(1-3), 94-113. https://doi.org/10.1504/IJETM.2002.000780

RAKLI. (2014). Kiinteistöalan yhteiskunnallinen ja Kansantaloudellinen merkitys (in Finnish). Retrieved from http://www.rakli.fi/media/tietoa-kiinteistoalasta/faktaa-alasta/2014_kiinteistoalan-yhteiskunnallinen-ja-kansantaloudellinen-merkitys_nettires.pdf

Reverte, C. (2016). Corporate social responsibility disclosure and market valuation: evidence from Spanish listed firms. Review of Managerial Science, 10(2), 411-435.

https://doi.org/10.1007/s11846-014-0151-7

Roberts, C. B. (1991). Environmental disclosures: a note on reporting practices in mainland Europe. Accounting, Auditing and Accountability, 4(3), 62-71.

https://doi.org/10.1108/09513579110005536

Robertson, D. C., \& Nicholson, N. (1996). Expressions of corporate social responsibility in U.K. firms. Journal of Business Ethics, 15, 1095-1106. https://doi.org/10.1007/BF00412050

ROTI. (2011). Rakennetun Omaisuuden Tila (in Finnish). Retrieved from http://roti.web31.neutech.fi/wpcontent/uploads/2015/12/ROTI_2011_kokonaan_sivuittain.pdf

Stacchezzini, R., Melloni, G., \& Lai, A. (2016). Sustainability management and reporting: the role of integrated reporting for communicating corporate sustainability management. Journal of Cleaner Production, 136, 102-110. https://doi.org/10.1016/j.jclepro.2016.01.109

Stibbe, R., \& Voigtländer, M. (2014). Corporate sustainability in the German real estate sector. Journal of Corporate Real Estate, 16(4), 239-251. https://doi.org/10.1108/JCRE-10-2013-0030 
Striukova, L., Unerman, J., \& Guthrie, J. (2008). Corporate reporting of intellectual capital: evidence from UK companies. British Accounting Review, 40(4), 297-313. https://doi.org/10.1016/j.bar.2008.06.001

Tavares, M. C. C., \& Rodrigues, L. L. (2016). The determinants of sustainability reporting of the Portuguese public sector entities. In A. C. S. Ferreira, G. M. C. Azevedo, J. S. Oliveira \& R. P. F. Marques (Eds.), Global perspectives on risk management and accounting in the public sector (pp. 226-251). The U.S.: Information Science Reference. https://doi.org/10.4018/978-1-4666-9803-1.ch012

Toivonen, S. (2011). Future office markets - the forces of change, and their impact on commercial aspirations of the Helsinki Metropolitan Area: Doctoral Thesis (in Finnish). Espoo: Aalto University.

Toivonen, S., \& Viitanen, K. (2015). Forces of change shaping the future commercial real estate market in the Helsinki Metropolitan Area in Finland. Land Use Policy, 42, 471-478. https://doi.org/10.1016/j.landusepol.2014.09.004

Toivonen, S., \& Viitanen, K. (2016). Environmental scanning and futures wheels as tools to analyze the possible future themes of the commercial real estate market. Land Use Policy, 52, 5161. https://doi.org/10.1016/j.landusepol.2015.12.011

Tsoutsoura, M. (2004). Corporate social responsibility and financial performance. Haas School of Business, Applied financial project, University of California, Berkeley. Retrieved from http://escholarship.org/uc/item/111799p2

UNEP FI Property Working Group. (2008). Responsible property investing: what the leaders are doing? Retrieved from http:// www.unepfi.org/fileadmin/documents/responsible_property_ investing_01.pdf
Unerman, J., \& Zappettini, F. (2014). Incorporating materiality considerations into analyses of absence from sustainability reporting. Social and Environmental Accountability Journal, 34(3), 172-186.

https://doi.org/10.1080/0969160X.2014.965262

Vuontisjärvi, T. (2006). Corporate social reporting in the European context and human resource disclosures: an analysis of Finnish companies. Journal of Business Ethics, 69, 331-354. https://doi.org/10.1007/s10551-006-9094-5

Wensen, K. V., Broer, W., Klein, J., \& Knopf, J. (2011). The state of play in sustainability reporting in the EU. Retrieved from http:// ec.europa.eu/social/BlobServlet?docId=6727\&langId=en

Wilkinson, S. J., \& Sayce, S. L. (2015). Introduction to sustainable property development. In S. J. Wilkinson, S. L. Sayce \& P. H. Christensen (Eds.), Developing Property Sustainability (pp. 1-64). Oxon: Routledge.

Willetts, R., Burdon, J., Glass, J., \& Frost, M. (2011). CR practices in engineering consultancies. International Journal of Construction Management, 11(2), 19-35. https://doi.org/10.1080/15623599.2011.10773166

Yildiz, A., \& Ozerim, G. (2014). Corporate social responsibility in European context. In D. Tuker, H. Toker \& C. Altuntas (Eds.), Contemporary issues in corporate social responsibility (pp. 43-55). USA: Lexington Books.

Zappettini, F., \& Unerman, J. (2016). 'Mixing' and 'Bending': the recontextualisation of discourses of sustainability in integrated reporting. Discourse and Communication, 10(5), 521-542. https://doi.org/10.1177/1750481316659175

Zuo, J., Zillante, G., Wilson, L., Davidson, K., \& Pullen, S. (2012). Sustainability policy of construction contractors: a review. Renewable and Sustainable Energy Reviews, 16(6), 3910-3916. https://doi.org/10.1016/j.rser.2012.03.011 